\title{
Risk-return dynamics: evidence from the energy and utilities sector in India
}

\author{
Banumathy, Karunanithy \\ Azhagaiah, Ramachandran \\ - ReCEIVED: 8 DeCEMBER 2014 \\ - ACCEPTED: 6 JuNE 2015
}

\begin{abstract}
The objective of the paper is to examine the risk and return dynamics of Indian stock returns and also to identify both the long-run and the short-run behaviour of stock returns using the daily closing price of the Bombay Stock Exchange 500 companies for a 10-year period from $1^{\text {st }}$ January 2003 to $31^{\text {st }}$ December 2012. Of the 500 companies, the study focuses on 12 companies from the Energy and Utilities sector. The results of the analyses of the relationship between stock returns and volatility based on daily data and using a Generalised Autoregressive Conditional Heteroscedasticity (GARCH-M $(1,1))$ model allows us to reject the null hypothesis of no significant relationship between risk and return of Chennai Petroleum Corporation Ltd. However, this hypothesis is accepted for all the other selected companies of the Indian Energy and Utilities sector.
\end{abstract}

\section{Keywords:}

GARCH model, GARCH-M model, Risk-return dynamics, Variance ratio test.

\section{JEL classification:}

C32, C1, G1.

Banumathy, K. Assistant Professor, Department of Management Studies, IFET College of Engenieering, (Affliated to Anna UniversityChennai, Gangarampalayam, Villupuram-605 108 Tamil Nadu, India.

E-mail: banukarunanithy@gmail.com

Azhagaiah, R. Department of Commerce, Kanchi Mamunivar Centre for Postgraduate Studies (Autonomous "A" Grade Centre with Potential for Excellence by UGC) (Government of Puducherry), Pondicherry University, Puducherry - 605 008, India.

E-mail:drrazhagaia@yahoo.co.in 


\title{
La dinámica riesgo-rendimiento: evidencia desde los sectores de la energía y los servicios públicos
}

\author{
Banumathy, Karunanithy \\ Azhagaiah, Ramachandran
}

\section{Resumen}

El objetivo del trabajo es examinar la dinámica riesgo-rendimiento en el mercado de valores indio, así como también identificar el comportamiento de los rendimientos tanto en el largo como en el corto plazo, utilizando para ello el precio de cierre diario de la Bolsa de Valores de Bombay 500 para el período comprendido entre el 1 de enero de 2003 y el 31 de diciembre de 2012. De las 500 empresas, este artículo se centra en doce empresas del sector de la Energía y los Servicios Públicos. El resultado de los análisis llevados a cabo, utilizando un modelo autorregresivo generalizado de heteroscedasticidad condicional en media (GARCH-M $(1,1)$ ), indica que la hipótesis nula de inexistencia de relación significativa entre el riesgo en el sector Energía y Servicios Públicos es rechazada para Chennai Petróleo Corporation Ltd., pero aceptada para las otras once empresas del sector consideradas en este artículo.

\section{Palabras clave:}

Modelo GARCH, modelo GARCH-M, dinámica riesgo-rendimiento, contraste de razón de varianzas. 


\section{Introduction}

The Indian stock market (SM) is one of the oldest in Asia and there are two leading stock exchanges in India: the National Stock Exchange (NSE) and the Bombay Stock Exchange (BSE).The Bombay Stock Exchange Ltd (BSE), established in 1875, is the oldest stock exchange both in India and in Asia as a whole. Over the past 137 years, the BSE has facilitated the growth of the Indian corporate sector by providing an efficient capital-raising platform.

The concept of risk plays a central role in peoples' lives, albeit in different forms. It affects decisions in a wide range of areas, including business, engineering, medicine and science. The term 'risk' generally refers to the possibility of a loss or other undesirable outcome; the analysis of risk-return trade-off is therefore fundamental in finance and requires accurate measures of risk. This relationship between risk and return has been studied using the capital asset pricing model (CAPM).

The CAPM is one of the important and widely-used models to explain the risk-return relationship. The theory postulates that there is a linear relationship between beta $(\beta)$ and return and investment analysts therefore use this model to evaluate investment projects, with reference to the equilibrium linear relationship between risk and the expected return on an asset. Bark (1991), Iqbal and Brooks (2007) and Michailidis and Tsopoglon (2007) found a relationship between risk and return, whereas, Choudhary and Choudhary (2010) showed strong evidence against the CAPM and concluded that risk had no effect on the expected return. Another model which examines the relationship between the risk and the return is the Arbitrage Pricing Theory (APT). Sentana (1997) and Gul and Khan (2013), among others, have evaluated stock returns using the APT model.

The advancement of econometric models has produced a new way of testing the CAPM according to the notion that the risk premium is conditional on time and the error term is non-normal and heteroscedastic. The Generalized Autoregressive Conditional Heteroscedasticity (GARCH) model extended by Bollerslev (1986) offers the advantage of handling time series data and can be considered an important improvement in CAPM specification as it allows the conditional variance of returns to be the measure of risk. The CAPM uses the actual return and the measure of risk is based on the unconditional distribution of the return, whereas the GARCH-inMean model (GARCH-M), a variation of the GARCH model that can be used to identify risk-return dynamics (Engle et al., 1987), uses the conditional variance of returns as a measure of risk, which is a much more realistic measure.

This article focuses on the Energy and Utilities sector because any nation's growth, encompassing all sectors of the economy and all sections of society, is contingent on 
meeting its energy requirements adequately. As a fast-growing economy, India has become one of the largest energy-intensive countries in the world, with energy representing a crucial input for India's development process. Hence, the energy sector is universally recognized as one of the most significant inputs for economic growth.

The energy sector comprises companies from the Petroleum, Gas and Power subsectors. The Energy and Utilities sector has not only survived financial turmoil, but has also emerged not just as a result of financial turmoil, but has also contributed to the rapid pace of global growth and change. Therefore, to meet the energy needs of all segments of India's population in the most efficient and cost-effective manner that ensures long-term sustainability, the CNX Energy Index has been developed to capture the performance of the companies in this sector.

Many earlier studies have tested the dynamics of risk and return in an Indian context as well as with reference to other countries. However, only a few studies have analysed the risk-return relationship with respect to certain sector indices as well as the individual stocks of various sectors. In this paper, we study the risk-return dynamics of individual stocks of India's Energy and Utilities sector using econometric modelisation. We also aim to test whether the returns of companies in this sector follow a random walk (RW) in both the long-run as well as in the short-run.

Thus, the hypotheses to be tested are as follows:

$H_{0}^{1}$ : There is no significant relationship between risk and return for the companies of the Energy and Utilities sector in India.

$H_{0}^{2}$ : Returns of the 12 companies of the Energy and Utilities sector in India follow a random walk.

In order to analyse the stylized facts regarding risk and returns and their joint dynamics, this study uses two different GARCH specifications, GARCH $(1,1)$ and GARCH-M $(1,1)$, and uses data from a 10-year period from $1^{\text {st }}$ January 2003 to $31^{\text {st }}$ December 2012. In addition, a variance ratio (VR) test has been used to identify the behaviour of returns, both in the long-run and the short-run. Though there have been many studies in this area, few of them have focused on a sector-wise analysis or on individual stocks. To cover this gap, therefore, the present study aims at identifying the risk-return dynamics.

The rest of the paper is organized as follows: Section 2 includes a literature review on the topic of risk-return dynamics. Section 3 presents the research methods used in the paper. Section 4 examines the risk-return dynamics and also the behaviour (random walk or not) of the returns of the companies under study using GARCH 
and VR modelisation. Section 5 summarizes and concludes, while section 6 offers suggestions for policy makers.

\section{Literature review}

There has been a large amount of literature on risk-return dynamics and modelling volatility in both developed and developing countries around the world. Numerous papers have used GARCH modelisation to study risk-return dynamics (see French et al., 1987; Baillie and DeGennaro, 1990; Chand et al., 2012; and Tah, 2013, among others), obtaining mixed results when considering the market indices of different stock exchanges and individual stocks. Zivanayi and Chinzara (2012) studied the nature of the relationship between risk and return with reference to particular sectors of the South African equity market and found significant negative dynamics.

Using a GARCH-M (1,1) model, Dean and Faff (2001) found a positive relationship between the market risk premium and its variance. Malik and Hassan (2004) stated that the health sector showed a significant decline in volatility persistence. Tang and Shum (2003) found a significant positive relationship between beta and return when the market was up and a negative relationship when the market was down. Budd and McCrohan (2012) found that the energy and cement sectors had the lowest beta values, which effectively predicted the sector-market relationship, while Karmakar (2005) showed a significant leverage effect using individual stocks.

There are relatively fewer empirical studies on the risk-return relationship with respect to particular sectors. For instance, Nateson et al. (2013) studied the spillover effect of BSE sector indices and found that the volatility spillover effect was positive and highly significant for all the sector-wise indices. Shanmugasundram and Benedict (2013) studied the risk factor across sector indices and found that there was no significant difference in the standard deviation among the various sector-wise indices; however there was a significant difference in risk at various time intervals.

On the other hand, a number of studies have tested the hypothesis that the return series exhibit RW behaviour. For instance, Ajayi and Karemera (1996) used variance ratio $(V R)$ tests to examine the random walk hypothesis ( $R W H$ ) for the currencies of eight Pacific Basin economies, and found that the RW specification is not consistent with market dynamics. Furthermore, many researchers have analysed the RW behaviour of different exchange rates. For instance, Chen (2008), Mbululu et al. (2013) and Wen (2009) tested the RWH of the spot prices of the petroleum products markets. Therefore, the VR test (Lo and MacKinlay, 1988) can be considered to be a powerful instrument when it comes to testing for RW. 
A large number of studies including Poterba and Summers (1988), Black (1990), Cecchetti et al. (1990), Kim et al. (1991) and Jog and Schaller (1994) found evidence of mean reversion in the return series. Although the literature on the $\mathrm{RWH}$ is extensive, there is no consensus among the researchers regarding long-run and short-run behaviour of the return in the Indian SM. Accordingly, we attempt in this paper to identify the behaviour of returns (RW or not) of the Energy and Utilities sector in the Indian SM for the period 2003-2012.

\section{Data and methods}

\subsection{Data source and period of the study}

The data used for the study comprises the daily closing prices of 12 companies from the Energy and Utilities sector over 10-year period from $1^{\text {st }}$ January 2003 to $31^{\text {st }}$ December 2012, collected from the Centre for Monitoring Indian Economy Pvt. Ltd. (CMIE) Prowess package.

\subsection{Research methods}

The statistical and econometric methods used in this paper include the normality test, the unit root test, the ARCH-LM test, the VR test and the GARCH family models. They were carried out using the econometric package E-views 7. All these tests are applied on the daily return series, that is, on the log of the first difference of daily closing prices.

More specifically, in order to provide an answer to the two questions studied in this paper, the first step is to use descriptive statistics to specify the distributional properties of the daily return series of the selected companies in order to test the normality of the return series. Second, the Augmented Dickey Fuller test (ADF) (Dickey-Fuller, 1979) is used to test whether the data are stationary or non-stationary. Third, to test for the presence of heteroscedasticity in the residuals of the return series, a Lagrange Multiplier (LM) test for autoregressive conditional heteroscedasticity $(\mathrm{ARCH})$ is used. Fourth, a VR test is used to analyse the behaviour of returns for the selected companies, in the short-run as well as in the long-run. Finally, after establishing the presence of the ARCH effect, two different univariate GARCH specifications, namely GARCH $(1,1)$ and GARCH-M $(1,1)$ are employed to model daily stock return volatility.

In order to specify the distributional properties of returns, the mean $(\bar{X})$, the standard deviation $\left(S_{x}\right)$, the skewness $(S)$ and kurtosis $(K)$ coefficients, and the Jarque-Bera statistics have been computed for the study period. In particular, the null and the alternative hypothesis for the Jarque-Bera test are as follow: 
$H_{0}$ : Returns are normally distributed

$H_{1}$ : Returns are not normally distributed

In order to test the stationary hypothesis in the daily return series, the Augmented Dickey-Fuller (ADF) test (Dickey-Fuller, 1979) is applied using the following three forms:

$$
\begin{gathered}
\Delta Y_{t}=\gamma_{1} y_{t-1}+\sum_{i=1}^{p} \beta_{i} \Delta y_{t-1}+\varepsilon_{t} \\
\Delta Y_{t}=\alpha_{0}+\gamma_{1} y_{t-1}+\sum_{i=1}^{p} \beta_{i} \Delta y_{t-1}+\varepsilon_{t} \\
\Delta Y_{t}=\alpha_{0}+\gamma_{1} y_{t-1}+\alpha_{2} t+\sum_{i=1}^{p} \beta_{i} \Delta y_{t-1}+\varepsilon_{t}
\end{gathered}
$$

$H_{0}$ : Series is non-stationary (There is unit root)

$H_{1}$ : Series is stationary (There is no unit root)

To test for the presence of heteroscedasticity in the residuals of the return series (a requisite of GARCH methodology), a Lagrange Multiplier (LM) test for autoregressive conditional heteroscedasticity $(\mathrm{ARCH})$ is used. It is advisable to carry out the Engle (1982) test for ARCH effect, where:

$$
\begin{aligned}
& H_{0}: \text { There is no ARCH effect } \\
& H_{1} \text { : There is ARCH effect }
\end{aligned}
$$

The VR test (Lo and MacKinlay, 1988) is used to identify the long-run or short-run behaviour of the selected companies' stock returns. Lo and Mackinlay (1988) tested the RWH using the VR test statistic mentioned below:

$$
X_{t}=\mu+X_{t-1}+\varepsilon_{t}
$$

where

$X_{t}=\log$ price process

$\mu=$ drift parameter

$\varepsilon_{t}=$ random disturbance error

The $V R$ statistic is given by the expression:

$$
\operatorname{VR}(q)=\frac{\frac{1 \operatorname{Var}}{q}\left(p_{t}-p_{t-q}\right)}{\operatorname{Var}\left(p_{t}-p_{t-1}\right)}=\frac{\sigma^{2}(q)}{\sigma^{2}(1)}
$$

where, Var is the variance operator, $q$ is a positive integer and the null hypothesis of RW implies $\operatorname{VR}(q)=1$. 
The RWH requires that the $V R$ for all the chosen intervals $(q)$ be equal to one. If $V R$ is less than one then the series is said to be 'mean reverting' and if VR is greater than one then the series is said to be 'persistent'. Lo and MacKinlay (1988) derived an asymptotic standard normal test statistic under the assumptions of both homoscedasticity $(Z(q))$ and heteroscedasticity $\left(Z^{*}(q)\right)$.

The rejection of RW under homoscedasticity could result from either heteroscedasticity or autocorrelation in the equity price series. If the heteroscedasticity RW is rejected then there is evidence of autocorrelation in the equity series.

The GARCH model developed by Bollerslev (1986) allows the conditional variance to be dependent on its previous own lags, so that the conditional variance equation in the simplest form is:

$$
\begin{array}{ll}
\text { Mean Equation: } & r_{t}=\mu+\varepsilon_{t} \\
\text { Variance Equation: } & \sigma_{t}^{2}=\omega+\alpha \varepsilon_{t-1}^{2}+\beta \sigma_{t-1}^{2}
\end{array}
$$

where

$r_{t}=$ return of the asset at time $t$

$\mu=$ Average return

$\varepsilon_{t}=$ Residual term at time $t$

$\omega=$ Constant term

$\alpha=$ Coefficient of the ARMA term

$\beta=$ Coefficient of the GARCH term

$\sigma_{t}^{2}=$ Conditional variance

Finally, the GARCH-M model is an extension of the GARCH model that allows the conditional mean to depend on its conditional variance.

$$
\begin{array}{ll}
\text { Mean Equation: } & r_{t}=\mu+\lambda \sigma_{t}^{2}+\varepsilon_{t} \\
\text { Variance Equation: } & \sigma_{t}^{2}=\omega+\alpha \varepsilon_{t-1}^{2}+\beta \sigma_{t-1}^{2}
\end{array}
$$

The parameter $\lambda$ in the mean equation is called the 'risk premium'; a positive $\lambda$ indicates that the return is positively related with volatility.

After this brief description of the methods used in this article, we should point out that the limitations of the study are as follows:

1. The present study focuses exclusively on individual companies and a particular sector rather than the market indices which were the focus of earlier studies.

2. The study used only 10 years' data from the Energy and Utilities sector of BSE 500 companies, i.e. from $1^{\text {st }}$ January 2003 to $31^{\text {st }}$ December 2012.

3. The study is confined to 12 companies of only one sector. 


\section{Results and discussion}

The descriptive statistics $\bar{X}, S_{x}, S, K$, as well as the Jarque-Bera statistics of returns for the 12 companies of the Indian Energy and Utilities sector are shown in Table 1. The mean return for HINDPET is negative $(-0.002)$, but is positive for all the other selected companies, implying a bullish market over the sample period. CESC's mean return is $0.108 \%$ on a daily basis, which is high when compared to all other companies. The standard deviation of the daily return series is high for HINDOIL (3.95), indicating high volatility in the series (see Table 1 ), and it is followed by RELINF, MRPL and CESC.

Generally speaking, a high mean return is matched with a high standard deviation. However, the descriptive statistics suggest that this is not always the case. It is evident that CESC accounts for a high mean return (0.108) while the lowest mean return (0.034) is recorded for RELINF. However, the highest standard deviation (3.95) is found for HINDOIL while that of GUJGAS is the lowest (2.07). Therefore, it can be inferred that there is no strong evidence of a positive relationship between risk and return for the companies in the Energy and Utilities sector in India.

Table 1. Descriptive statistics of stock returns of the energy and utilities sector, 2003-2012

\begin{tabular}{lcccccc}
\hline Firm & Mean & $\begin{array}{c}\text { Standard } \\
\text { Deviation }\left(\boldsymbol{S}_{\boldsymbol{x}}\right)\end{array}$ & $\begin{array}{c}\text { Skewness } \\
(\boldsymbol{S})\end{array}$ & $\begin{array}{c}\text { Kurtosis } \\
(\boldsymbol{K})\end{array}$ & $\begin{array}{c}\text { Jarque-Bera } \\
\text { Statistic }\end{array}$ & Sig \\
\hline BHARPET & 0.047 & 2.46 & 0.343 & 6.25 & $1145.10^{*}$ & 0.0000 \\
\hline CESC & 0.108 & 3.07 & 0.406 & 7.53 & $2206.90^{*}$ & 0.0000 \\
\hline CPCL & 0.064 & 2.83 & 0.087 & 12.88 & $10145.38^{*}$ & 0.0000 \\
\hline GAIL & 0.082 & 2.47 & -0.004 & 18.31 & $24375.49^{*}$ & 0.0000 \\
\hline GUJGAS & 0.073 & 2.07 & 0.159 & 14.67 & $14165.70^{*}$ & 0.0000 \\
\hline HINDOIL & 0.065 & 3.95 & 0.484 & 7.16 & $1899.26^{*}$ & 0.0000 \\
\hline HINDPET & -0.002 & 2.51 & 0.170 & 7.19 & $1835.49^{*}$ & 0.0000 \\
\hline MRPL & 0.105 & 3.24 & 0.906 & 10.82 & $6694.67^{*}$ & 0.0000 \\
\hline ONGC & 0.062 & 2.22 & -0.155 & 8.36 & $2999.09^{*}$ & 0.0000 \\
\hline RELIND & 0.070 & 2.35 & -1.015 & 18.34 & $24904.93^{*}$ & 0.0000 \\
\hline RELINF & 0.034 & 3.30 & -0.453 & 11.50 & $7594.95^{*}$ & 0.0000 \\
\hline TATPWR & 0.093 & 2.56 & -0.198 & 10.34 & $5618.52^{*}$ & 0.0000 \\
\hline ALL Companies & 0.062 & 1.80 & -0.873 & 12.60 & $9892.24^{*}$ & 0.0000 \\
\hline
\end{tabular}

SOURCE: COMPUTED RESULTS BASED ON COMPILED DATA COLLECTED FROM CMIE PROWESS PACKAGE.

*Significant at the $1 \%$ level. 
In Table 1 it can also be seen that the returns are negatively skewed for GAIL, ONGC, RELIND, RELINF and TATPWR stocks and positively skewed for the rest; in addition, there is an excess of kurtosis for the returns of all the companies. The values of both coefficients suggest that the return series are not normally distributed, a finding also supported by the Jarque-Bera statistic, which is significant at the $1 \%$ level for all 12 companies and therefore for the sector as a whole.

In order to test for the stationarity of the series, the ADF test on the raw data (daily closing price) is conducted and the results are presented in Table 2 . The log of first difference of daily closing price will be used if the stationarity of the raw data is rejected.

Table 2. Results of the unit root test for stock returns of the energy and utilities sector, 2003-2012

\begin{tabular}{lcccc}
\hline \multirow{2}{*}{ Firm } & \multicolumn{2}{c}{ Levels } & \multicolumn{2}{c}{ First Difference } \\
\cline { 2 - 5 } & ADF Statistics & Sig & ADF Statistics & Sig \\
\hline BHARPET & -0.59 & 0.4609 & $-50.33^{*}$ & 0.0001 \\
\hline CESC & -0.39 & 0.5433 & $-45.53^{*}$ & 0.0001 \\
\hline CPCL & -0.63 & 0.4440 & $-45.23^{*}$ & 0.0001 \\
\hline GAIL & -0.11 & 0.6462 & $-50.54^{*}$ & 0.0001 \\
\hline GUJGAS & -1.13 & 0.2370 & $-50.31^{*}$ & 0.0001 \\
\hline HINDOIL & -0.75 & 0.3909 & $-48.49^{*}$ & 0.0001 \\
\hline HINDPET & -0.66 & 0.4295 & $-47.14^{*}$ & 0.0001 \\
\hline MRPL & -0.72 & 0.4048 & $-45.06^{*}$ & 0.0001 \\
\hline ONGS & -0.81 & 0.3644 & $-48.67^{*}$ & 0.0001 \\
\hline RELIND & -0.68 & 0.4233 & $-30.98^{*}$ & 0.0000 \\
\hline RELINF & -0.93 & 0.3132 & $-46.67^{*}$ & 0.0001 \\
\hline TATPWR & -0.85 & 0.3461 & $-48.36^{*}$ & 0.0001 \\
\hline ALL Companies (Average) & & & $-44.15^{*}$ & 0.0001 \\
\hline MacKinnon One-Sided Test Critical Values & $1 \%$ level & $5 \%$ level & $10 \%$ level \\
\hline
\end{tabular}

SOURCE: COMPUTED RESULTS BASED ON COMPILED DATA COLLECTED FROM CMIE PROWESS PACKAGE.

*Significant at the $1 \%$ level.

From Table 2, it can be seen that the $p$-values of the ADF test lead to the non-rejection of the null hypothesis of non-stationarity for all the companies. Therefore, first differences in the prices are carried out with the subsequent ADF test statistics revealing a significant probability $(0.0001)$ for all the selected companies, and thus providing evidence for rejecting the null hypothesis of a unit root for all the companies and for the sector as a whole. Hence, the ADF test for first differences indicates stationarity, meaning that the GARCH model can be applied. 
The Lagrange multiplier (LM) test for ARCH effect in the residuals (Engle, 1982) is estimated using an ARMA $(1,1)$ specification, and the results are presented in Table 4. Various standard procedures are available to test for the existence of ARCH effects, including the White heteroscedasticity test (White, 1980), the Breusch-Godfrey test and the Durbin-Watson test, however, a commonly used test is the Lagrange multiplier (LM) test.

Table 3. Results of initial ARCH-LM test for stocks of the energy and utilities sector, 2003-2012

\begin{tabular}{|c|c|c|c|c|}
\hline Firm & F Statistic & $\begin{array}{c}\text { Prob. F } \\
(1,2492)\end{array}$ & $\begin{array}{c}\text { Obs }^{\star} \\
\text { R-Squared }\left(T R^{2}\right)\end{array}$ & $\begin{array}{c}\text { Prob. } \\
\text { Chi-Square (1) }\end{array}$ \\
\hline BHARPET & $28.67^{\star}$ & 0.00 & $28.37^{\star}$ & 0.00 \\
\hline CESC & $126.55^{\star}$ & 0.00 & $120.53^{*}$ & 0.00 \\
\hline CPCL & $247.23^{\star}$ & 0.00 & $225.10^{\star}$ & 0.00 \\
\hline GAIL & $838.09^{*}$ & 0.00 & $627.67^{\star}$ & 0.00 \\
\hline GUJGAS & $34.75^{\star}$ & 0.00 & $34.30^{*}$ & 0.00 \\
\hline HINDOIL & $168.88^{*}$ & 0.00 & $158.29^{\star}$ & 0.00 \\
\hline HINDPET & $91.24^{*}$ & 0.00 & $88.09^{*}$ & 0.00 \\
\hline MRPL & $140.16^{*}$ & 0.00 & $132.81^{*}$ & 0.00 \\
\hline ONGS & $85.30^{*}$ & 0.00 & $82.54^{*}$ & 0.00 \\
\hline RELIND & $35.24^{*}$ & 0.00 & $34.77^{\star}$ & 0.00 \\
\hline RELINF & $180.79^{*}$ & 0.00 & $168.69^{*}$ & 0.00 \\
\hline TATPWR & $494.67^{\star}$ & 0.00 & $413.07^{\star}$ & 0.00 \\
\hline $\begin{array}{l}\text { ALL Companies } \\
\text { (Average) }\end{array}$ & $424.01^{*}$ & 0.00 & $362.65^{\star}$ & 0.00 \\
\hline
\end{tabular}

SOURCE: COMPUTED RESULTS BASED ON COMPILED DATA COLLECTED FROM CMIE PROWESS PACKAGE.

*Significant at the $1 \%$ level.

It can be inferred from Table 3 that the $F$ statistics of the ARMA $(1,1)$ model as well as the $T R^{2}$ under the $\chi^{2}$ distribution with one degree of freedom are significant at the $1 \%$ level for all the sample companies. Therefore, it is evident that ARCH effects exist in the series of residuals and hence the variances of the daily return series of all the companies of the Energy and Utilities sector are non-constant. As a consequence, the implementation of GARCH models is required in order to study the volatility and the risk-return dynamic.

Table 4 lists the results obtained from the estimation of the GARCH $(1,1)$ and GARCH- $M$ models. From the table, it can be inferred that $\mu$ is significant for CESC, CPCL, GAIL, GUJGAS, ONGC, RELIND and TATPWR in the mean equation of the 
GARCH $(1,1)$. In the variance equation of the GARCH $(1,1)$ specification, the coefficients on both the lagged squared residuals and on the lagged conditional variance are statistically highly significant and the sum of them is very close to one, hence shocks to the conditional variance are highly persistent in nature in the Energy and Utilities sector of India.

Table 4. Estimated results of GARCH $(1,1)$ and GARCH-M $(1,1)$ models for stocks of the energy and utilities sector, 2003-2012

\begin{tabular}{|c|c|c|c|c|c|c|c|c|c|}
\hline \multirow[b]{2}{*}{ Firm } & \multirow[b]{2}{*}{ Model } & \multicolumn{2}{|c|}{ Mean Equation } & \multicolumn{4}{|c|}{ Variance Equation } & \multicolumn{2}{|c|}{ ARCH-LM Test } \\
\hline & & $\begin{array}{c}\text { Constant } \\
(\mu)\end{array}$ & $\begin{array}{c}\text { Risk } \\
\text { Premium } \\
(\lambda)\end{array}$ & $\begin{array}{c}\text { Constant } \\
(\omega)\end{array}$ & $\begin{array}{c}\text { ARCH } \\
\text { Effect } \\
(\alpha)\end{array}$ & $\begin{array}{c}\text { GARCH } \\
\text { Effect } \\
(\beta)\end{array}$ & $\begin{array}{l}\text { Both } \\
(\alpha+\beta)\end{array}$ & F Statistic & $\mathrm{Obs}^{\star} R^{2}$ \\
\hline \multirow{2}{*}{ BHARPET } & GARCH & $\begin{array}{l}0.059 \\
(1.31)\end{array}$ & & $\begin{array}{l}0.044^{*} \\
(3.85)\end{array}$ & $\begin{array}{c}0.033^{\star} \\
(10.85)\end{array}$ & $\begin{array}{c}0.960^{\star} \\
(287.44)\end{array}$ & 0.9929 & $\begin{array}{c}1.9992 \\
{[0.1575]}\end{array}$ & $\begin{array}{c}1.9992 \\
{[0.1574]}\end{array}$ \\
\hline & GARCH-M & $\begin{array}{l}0.033 \\
(0.33)\end{array}$ & $\begin{array}{l}0.005 \\
(0.29)\end{array}$ & $\begin{array}{l}0.044^{*} \\
(3.86)\end{array}$ & $\begin{array}{c}0.033^{\star} \\
(10.83)\end{array}$ & $\begin{array}{c}0.960 * \\
(288.57)\end{array}$ & 0.9929 & $\begin{array}{c}2.0288 \\
{[0.1545]}\end{array}$ & $\begin{array}{c}2.0288 \\
{[0.1543]}\end{array}$ \\
\hline \multirow{2}{*}{ CESC } & GARCH & $\begin{array}{c}0.115^{\star *} \\
(2.20)\end{array}$ & & $\begin{array}{c}0.328^{*} \\
(7.23)\end{array}$ & $\begin{array}{c}0.112^{\star} \\
(14.16)\end{array}$ & $\begin{array}{l}0.857^{\star} \\
(95.19)\end{array}$ & 0.9694 & $\begin{array}{c}3.8646 \\
{[0.0494]}\end{array}$ & $\begin{array}{c}3.8618 \\
{[0.0494]}\end{array}$ \\
\hline & GARCH-M & $\begin{array}{l}0.047 \\
(0.48) \\
\end{array}$ & $\begin{array}{l}0.010 \\
(0.81) \\
\end{array}$ & $\begin{array}{c}0.324^{\star} \\
(7.16)\end{array}$ & $\begin{array}{c}0.111^{*} \\
(14.06)\end{array}$ & $\begin{array}{l}0.859^{*} \\
(96.49)\end{array}$ & 0.9697 & $\begin{array}{c}3.7947 \\
{[0.0515]}\end{array}$ & $\begin{array}{c}3.7919 \\
{[0.0515]}\end{array}$ \\
\hline \multirow{2}{*}{ CPCL } & GARCH & $\begin{array}{l}-0.011 \\
(-0.27)\end{array}$ & & $\begin{array}{l}0.093^{*} \\
(14.35)\end{array}$ & $\begin{array}{l}0.084^{*} \\
(16.86)\end{array}$ & $\begin{array}{c}0.911^{\star} \\
(241.45)\end{array}$ & 0.9950 & $\begin{array}{c}3.4786 \\
{[0.0623]}\end{array}$ & $\begin{array}{c}3.4765 \\
{[0.0622]}\end{array}$ \\
\hline & GARCH-M & $\begin{array}{c}-0.126^{\star \star} \\
(-2.08)\end{array}$ & $\begin{array}{c}0.024^{\star *} \\
(2.32)\end{array}$ & $\begin{array}{l}0.092^{\star} \\
(13.50)\end{array}$ & $\begin{array}{l}0.085^{\star} \\
(16.58)\end{array}$ & $\begin{array}{c}0.911^{\star} \\
(227.27)\end{array}$ & 0.9953 & $\begin{array}{c}3.4626 \\
{[0.0629]}\end{array}$ & $\begin{array}{c}3.4606 \\
{[0.0628]}\end{array}$ \\
\hline \multirow{2}{*}{ GAIL } & GARCH & $\begin{array}{c}0.096^{\star *} \\
(2.44)\end{array}$ & & $\begin{array}{l}0.101^{*} \\
(5.92)\end{array}$ & $\begin{array}{l}0.087^{\star} \\
(15.91)\end{array}$ & $\begin{array}{c}0.899 * \\
(139.76)\end{array}$ & 0.9854 & $\begin{array}{c}1.2468 \\
{[0.2643]}\end{array}$ & $\begin{array}{c}1.2472 \\
{[0.2641]}\end{array}$ \\
\hline & GARCH-M & $\begin{array}{l}0.077 \\
(1.23)\end{array}$ & $\begin{array}{l}0.005 \\
(0.39) \\
\end{array}$ & $\begin{array}{c}0.100^{*} \\
(5.90)\end{array}$ & $\begin{array}{l}0.087^{\star} \\
(15.93)\end{array}$ & $\begin{array}{c}0.899^{*} \\
(140.25)\end{array}$ & 0.9854 & $\begin{array}{c}1.3292 \\
{[0.2491]}\end{array}$ & $\begin{array}{c}1.3296 \\
{[0.2489]}\end{array}$ \\
\hline \multirow{2}{*}{ GUJGAS } & GARCH & $\begin{array}{c}0.079^{\star \star} \\
(2.09)\end{array}$ & & $\begin{array}{l}1.930^{*} \\
(12.14)\end{array}$ & $\begin{array}{c}0.180^{\star} \\
(9.79)\end{array}$ & $\begin{array}{c}0.387^{\star} \\
(8.29)\end{array}$ & 0.5678 & $\begin{array}{c}0.0954 \\
{[0.7575]}\end{array}$ & $\begin{array}{c}0.0955 \\
{[0.7573]}\end{array}$ \\
\hline & GARCH-M & $\begin{array}{l}0.230 \\
(1.95) \\
\end{array}$ & $\begin{array}{l}-0.038 \\
(-1.34) \\
\end{array}$ & $\begin{array}{l}1.944^{*} \\
(11.61)\end{array}$ & $\begin{array}{c}0.175^{\star} \\
(9.54)\end{array}$ & $\begin{array}{c}0.387^{\star} \\
(7.89)\end{array}$ & 0.5622 & $\begin{array}{c}0.1096 \\
{[0.7406]}\end{array}$ & $\begin{array}{c}0.1097 \\
{[0.7405]}\end{array}$ \\
\hline \multirow{2}{*}{ HINDOIL } & GARCH & $\begin{array}{l}0.030 \\
(0.41)\end{array}$ & & $\begin{array}{l}0.712^{*} \\
(8.10)\end{array}$ & $\begin{array}{l}0.094^{\star} \\
(11.42)\end{array}$ & $\begin{array}{l}0.863^{*} \\
(82.71)\end{array}$ & 0.9571 & $\begin{array}{c}1.4607 \\
{[0.2269]}\end{array}$ & $\begin{array}{c}1.4610 \\
{[0.2268]}\end{array}$ \\
\hline & GARCH-M & $\begin{array}{l}-0.189 \\
(-1.20) \\
\end{array}$ & $\begin{array}{l}0.018 \\
(1.55) \\
\end{array}$ & $\begin{array}{c}0.699^{\star} \\
(8.10)\end{array}$ & $\begin{array}{l}0.092^{*} \\
(11.33)\end{array}$ & $\begin{array}{l}0.866^{*} \\
(84.28)\end{array}$ & 0.9577 & $\begin{array}{c}1.8138 \\
{[0.1782]}\end{array}$ & $\begin{array}{c}1.8139 \\
{[0.1780]}\end{array}$ \\
\hline \multirow{2}{*}{ HINDPET } & GARCH & $\begin{array}{l}0.001 \\
(0.02)\end{array}$ & & $\begin{array}{l}0.254^{\star} \\
(6.04)\end{array}$ & $\begin{array}{c}0.087^{\star} \\
(9.93)\end{array}$ & $\begin{array}{l}0.873^{*} \\
(65.69)\end{array}$ & 0.9603 & $\begin{array}{c}1.9620 \\
{[0.1614]}\end{array}$ & $\begin{array}{c}1.9620 \\
{[0.1613]}\end{array}$ \\
\hline & GARCH-M & $\begin{array}{l}-0.065 \\
(-0.65) \\
\end{array}$ & $\begin{array}{l}0.013 \\
(0.74) \\
\end{array}$ & $\begin{array}{l}0.254^{*} \\
(6.04) \\
\end{array}$ & $\begin{array}{c}0.087^{\star} \\
(9.95)\end{array}$ & $\begin{array}{l}0.873^{\star} \\
(65.66)\end{array}$ & 0.9603 & $\begin{array}{c}2.1342 \\
{[0.1442]}\end{array}$ & $\begin{array}{c}2.1341 \\
{[0.1441]}\end{array}$ \\
\hline \multirow{2}{*}{ MRPL } & GARCH & $\begin{array}{l}0.053 \\
(0.94)\end{array}$ & & $\begin{array}{l}0.509^{\star} \\
(11.80)\end{array}$ & $\begin{array}{l}0.153^{\star} \\
(15.61)\end{array}$ & $\begin{array}{l}0.808^{\star} \\
(79.05)\end{array}$ & 0.9616 & $\begin{array}{c}3.5708 \\
{[0.0589]}\end{array}$ & $\begin{array}{c}3.5686 \\
{[0.0589]}\end{array}$ \\
\hline & GARCH-M & $\begin{array}{l}0.009 \\
(0.10)\end{array}$ & $\begin{array}{l}0.006 \\
(0.56)\end{array}$ & $\begin{array}{l}0.510^{\star} \\
(11.86)\end{array}$ & $\begin{array}{c}0.153^{\star} \\
(15.05)\end{array}$ & $\begin{array}{l}0.808^{\star} \\
(78.52)\end{array}$ & 0.9614 & $\begin{array}{c}3.6368 \\
{[0.0566]}\end{array}$ & $\begin{array}{c}3.6345 \\
{[0.0566]}\end{array}$ \\
\hline \multirow{2}{*}{ ONGC } & GARCH & $\begin{array}{c}0.079 * * \\
(2.27)\end{array}$ & & $\begin{array}{l}0.084^{*} \\
(6.04)\end{array}$ & $\begin{array}{l}0.089^{*} \\
(12.47)\end{array}$ & $\begin{array}{c}0.897^{\star} \\
(118.49)\end{array}$ & 0.9861 & $\begin{array}{c}8.0852 \\
{[0.0045]}\end{array}$ & $\begin{array}{c}8.0655 \\
{[0.0045]}\end{array}$ \\
\hline & GARCH-M & $\begin{array}{l}0.063 \\
(1.01)\end{array}$ & $\begin{array}{l}0.005 \\
(0.32)\end{array}$ & $\begin{array}{l}0.084^{*} \\
(5.92)\end{array}$ & $\begin{array}{l}0.089^{*} \\
(12.46)\end{array}$ & $\begin{array}{c}0.897^{\star} \\
(117.53)\end{array}$ & 0.9861 & $\begin{array}{c}8.2758 \\
{[0.0041]}\end{array}$ & $\begin{array}{c}8.2550 \\
{[0.0041]}\end{array}$ \\
\hline
\end{tabular}




\begin{tabular}{|c|c|c|c|c|c|c|c|c|c|}
\hline \multirow[b]{2}{*}{ Firm } & \multirow[b]{2}{*}{ Model } & \multicolumn{2}{|c|}{ Mean Equation } & \multicolumn{4}{|c|}{ Variance Equation } & \multicolumn{2}{|c|}{ ARCH-LM Test } \\
\hline & & $\begin{array}{l}\text { Constant } \\
\qquad(\mu)\end{array}$ & $\begin{array}{c}\text { Risk } \\
\text { Premium } \\
(\lambda)\end{array}$ & $\begin{array}{c}\text { Constant } \\
(\omega)\end{array}$ & $\begin{array}{c}\text { ARCH } \\
\text { Effect } \\
(\alpha)\end{array}$ & $\begin{array}{c}\text { GARCH } \\
\text { Effect } \\
(\beta)\end{array}$ & $\begin{array}{l}\text { Both } \\
(\alpha+\beta)\end{array}$ & F Statistic & $\mathrm{Obs}^{\star} R^{2}$ \\
\hline \multirow{2}{*}{ RELIND } & GARCH & $\begin{array}{c}0.080^{\star *} \\
(2.17)\end{array}$ & & $\begin{array}{c}0.330^{\star} \\
(8.91)\end{array}$ & $\begin{array}{l}0.203^{\star} \\
(31.24)\end{array}$ & $\begin{array}{c}0.751^{\star} \\
(68.87)\end{array}$ & 0.9536 & $\begin{array}{c}5.5709 \\
{[0.0183]}\end{array}$ & $\begin{array}{c}5.5629 \\
{[0.0183]}\end{array}$ \\
\hline & GARCH-M & $\begin{array}{l}0.059 \\
(0.94)\end{array}$ & $\begin{array}{l}0.005 \\
(0.38)\end{array}$ & $\begin{array}{c}0.330^{\star} \\
(8.87)\end{array}$ & $\begin{array}{l}0.203^{*} \\
(30.71)\end{array}$ & $\begin{array}{c}0.751^{\star} \\
(67.98)\end{array}$ & 0.9537 & $\begin{array}{c}5.6964 \\
{[0.0171]}\end{array}$ & $\begin{array}{c}5.6880 \\
{[0.0171]}\end{array}$ \\
\hline \multirow{2}{*}{ RELINF } & GARCH & $\begin{array}{l}0.038 \\
(0.79)\end{array}$ & & $\begin{array}{l}0.198^{\star} \\
(10.08)\end{array}$ & $\begin{array}{l}0.140 * \\
(24.33)\end{array}$ & $\begin{array}{c}0.853^{*} \\
(152.67)\end{array}$ & 0.9934 & $\begin{array}{l}15.1550 \\
{[0.0001]}\end{array}$ & $\begin{array}{l}15.0755 \\
{[0.0001]}\end{array}$ \\
\hline & GARCH-M & $\begin{array}{l}-0.016 \\
(-0.24)\end{array}$ & $\begin{array}{l}0.009 \\
(1.15)\end{array}$ & $\begin{array}{l}0.199^{\star} \\
(10.21)\end{array}$ & $\begin{array}{l}0.140^{\star} \\
(24.29)\end{array}$ & $\begin{array}{c}0.853^{*} \\
(153.85)\end{array}$ & 0.9934 & $\begin{array}{l}14.7677 \\
{[0.0001]}\end{array}$ & $\begin{array}{l}14.6925 \\
{[0.0001]}\end{array}$ \\
\hline \multirow{2}{*}{ TATPWR } & GARCH & $\begin{array}{l}0.117^{\star} \\
(3.04)\end{array}$ & & $\begin{array}{l}0.117^{\star} \\
(6.28)\end{array}$ & $\begin{array}{c}0.126^{\star} \\
(13.75)\end{array}$ & $\begin{array}{l}0.860^{\star} \\
(97.76)\end{array}$ & 0.9868 & $\begin{array}{c}4.1284 \\
{[0.0423]}\end{array}$ & $\begin{array}{c}4.1248 \\
{[0.0423]}\end{array}$ \\
\hline & GARCH-M & $\begin{array}{l}0.102 \\
(1.72)\end{array}$ & $\begin{array}{l}0.004 \\
(0.33)\end{array}$ & $\begin{array}{l}0.117^{\star} \\
(6.24)\end{array}$ & $\begin{array}{c}0.126^{\star} \\
(13.76)\end{array}$ & $\begin{array}{l}0.861^{\star} \\
(97.71)\end{array}$ & 0.9868 & $\begin{array}{c}4.2599 \\
{[0.0391]}\end{array}$ & $\begin{array}{c}4.2561 \\
{[0.0391]}\end{array}$ \\
\hline \multirow{2}{*}{ ALL } & GARCH & $\begin{array}{l}0.072^{\star} \\
(2.63)\end{array}$ & & $\begin{array}{l}0.050^{\star} \\
(6.44)\end{array}$ & $\begin{array}{c}0.108^{\star} \\
(16.34)\end{array}$ & $\begin{array}{c}0.881^{\star} \\
(158.51)\end{array}$ & 0.9889 & $\begin{array}{c}2.6472 \\
{[0.1039]}\end{array}$ & $\begin{array}{c}2.6465 \\
{[0.1038]}\end{array}$ \\
\hline & GARCH-M & $\begin{array}{l}0.036 \\
(0.84)\end{array}$ & $\begin{array}{l}0.018^{*} \\
(0.99)\end{array}$ & $\begin{array}{l}0.050^{*} \\
(6.39)\end{array}$ & $\begin{array}{c}0.108^{*} \\
(16.44)\end{array}$ & $\begin{array}{c}0.881^{*} \\
(158.49)\end{array}$ & 0.9868 & $\begin{array}{c}2.7942 \\
{[0.0947]}\end{array}$ & $\begin{array}{c}2.7933 \\
{[0.0947]}\end{array}$ \\
\hline
\end{tabular}

SOURCE: COMPUTED RESULTS BASED ON COMPILED DATA COLLECTED FROM CMIE PROWESS PACKAGE.

Figures in curved brackets are $\mathrm{z}$ statistics; Figures in square brackets are p-values.

*Significant at the $1 \%$ level; **Significant at the $5 \%$ level.

As for the results obtained from the estimation of a GARCH-M $(1,1)$ model, the estimated coefficient of $\sigma^{2}$ (conditional variance) in the mean equation is negative and insignificant for GUJGAS stock $(\lambda=-0.038)$, which indicates that the risk due to conditional volatility tends to reduce the return, but this effect is not significant. The $\omega$, $\alpha$ and $\beta$ of the variance equation for the selected companies are significant at the $1 \%$ level. The sum of $\alpha$ and $\beta$ is very close to one for BHARPET, CPCL, GAIL, ONGC, RELINF and TATPWR stock (0.99), revealing a high persistence of volatility.

Finally, out of 12 selected companies in the sector, only CPCL stock showed a significant $\lambda(0.024)$, indicating a direct relationship between risk and return. Moreover, the intercept of CPCL is significant in both the mean and the variance equations. Hence, the $H_{0}^{1}$ "there is no significant relationship between risk and return for the companies of the Energy and Utilities sector in India" is rejected only for CPCL while it is accepted for all the other companies.

Table 5 shows the results of the $V R$ test for sample intervals of 30,60, 90,120,180, 240, 360 and 480 days, and for each lag the estimate of the VR and the test statistics for the null hypotheses of homoscedasticity $Z(q)$, and heteroscedasticity $Z^{*}(q)$ are calculated for all the companies of the Energy and Utilities sector.

From Table 5 it can be seen that $V R$ decreases when the lags of $q$ increase and the VR is less than one for all the selected lags of all 12 companies, which provides evidence 
of a negative serial correlation in the share price returns. The test statistics estimated under the assumption of homoscedasticity are significant for all the lags of all the companies. This allows us to reject the RWH in the return series both for the shortrun as well as for the long-run. However, the rejection may be attributed to the presence of heteroscedasticity or serial correlation in the data series.

Table 5. Results of the variance ratio test of daily return series of stocks of the energy and utilities sector, 2003-2012

\begin{tabular}{|c|c|c|c|c|c|c|c|c|c|}
\hline \multirow{2}{*}{ Firm } & \multirow{2}{*}{$\begin{array}{c}\text { Estimates } \\
\& \text { Test } \\
\text { Statistics }\end{array}$} & \multicolumn{8}{|c|}{ Lags ( $q$ Days) } \\
\hline & & $q=30$ & $q=60$ & $q=90$ & $q=120$ & $q=180$ & $q=240$ & $q=360$ & $q=480$ \\
\hline \multirow{3}{*}{ BHARPET } & $V R$ & 0.034 & 0.017 & 0.012 & 0.009 & 0.006 & 0.004 & 0.003 & 0.002 \\
\hline & $Z(q)$ & $-7.83^{\star}$ & $-5.56^{\star}$ & $-4.55^{\star}$ & $-3.94^{*}$ & $-3.22^{\star}$ & $-2.79^{*}$ & $-2.28^{\star \star}$ & $-1.97^{\star \star}$ \\
\hline & $Z^{\star}(q)$ & $-6.53^{*}$ & $-4.78^{\star}$ & $-3.96^{\star}$ & $-3.46^{\star}$ & $-2.86^{\star}$ & $-2.50^{\star *}$ & $-2.08^{\star *}$ & -1.83 \\
\hline \multirow{3}{*}{ CESC } & $V R$ & 0.036 & 0.019 & 0.012 & 0.009 & 0.006 & 0.004 & 0.003 & 0.002 \\
\hline & $Z(q)$ & $-7.81^{\star}$ & $-5.55^{\star}$ & $-4.54^{*}$ & $-3.94^{*}$ & $-3.22^{\star}$ & $-2.79^{\star}$ & $-2.28^{\star *}$ & $-1.97^{\star \star}$ \\
\hline & $Z^{\star}(q)$ & $-6.06^{*}$ & $-4.53^{*}$ & $-3.80^{*}$ & $-3.35^{\star}$ & $-2.80^{\star}$ & $-2.46^{\star \star}$ & $-2.07^{\star \star}$ & -1.84 \\
\hline \multirow{3}{*}{ CPCL } & $V R$ & 0.039 & 0.020 & 0.013 & 0.010 & 0.006 & 0.005 & 0.003 & 0.002 \\
\hline & $Z(q)$ & $-7.79^{\star}$ & $-5.54^{\star}$ & $-4.54^{*}$ & $-3.94^{*}$ & $-3.22^{\star}$ & $-2.79^{*}$ & $-2.28^{\star \star}$ & $-1.97^{\star \star}$ \\
\hline & $Z^{\star}(q)$ & $-5.76^{*}$ & $-4.34^{*}$ & $-3.65^{\star}$ & $-3.21^{\star}$ & $-2.68^{\star}$ & $-2.36^{\star *}$ & $-1.97^{\star *}$ & -1.74 \\
\hline \multirow{3}{*}{ GAIL } & $V R$ & 0.033 & 0.016 & 0.011 & 0.008 & 0.006 & 0.004 & 0.003 & 0.002 \\
\hline & $Z(q)$ & $-7.83^{\star}$ & $-5.57^{\star}$ & $-4.55^{\star}$ & $-3.94^{*}$ & $-3.22^{\star}$ & $-2.79^{*}$ & $-2.28^{\star *}$ & $-1.97^{* \star}$ \\
\hline & $Z^{\star}(q)$ & $-4.78^{*}$ & $-3.92^{\star}$ & $-3.43^{*}$ & $-3.08^{*}$ & $-2.61^{*}$ & $-2.32^{\star *}$ & $-1.97^{\star \star}$ & -1.76 \\
\hline \multirow{3}{*}{ GUJGAS } & $V R$ & 0.034 & 0.017 & 0.011 & 0.008 & 0.005 & 0.004 & 0.003 & 0.002 \\
\hline & $Z(q)$ & $-7.82^{*}$ & $-5.56^{\star}$ & $-4.55^{\star}$ & $-3.94^{*}$ & $-3.22^{\star}$ & $-2.79^{\star}$ & $-2.28^{\star \star}$ & $-1.97^{\star \star}$ \\
\hline & $Z^{\star}(q)$ & $-6.27^{\star}$ & $-4.93^{*}$ & $-4.18^{*}$ & $-3.69^{*}$ & $-3.09^{*}$ & $-2.71^{\star}$ & $-2.26^{\star *}$ & $-1.98^{\star \star}$ \\
\hline \multirow{3}{*}{ HINDOIL } & $V R$ & 0.036 & 0.017 & 0.012 & 0.009 & 0.006 & 0.004 & 0.003 & 0.002 \\
\hline & $Z(q)$ & $-7.81^{*}$ & $-5.56^{*}$ & $-4.55^{*}$ & $-3.94^{*}$ & $-3.22^{*}$ & $-2.79^{\star}$ & $-2.28^{\star *}$ & $-1.97^{* \star}$ \\
\hline & $Z^{\star}(q)$ & $-6.12^{\star}$ & $-4.66^{\star}$ & $-3.93^{\star}$ & $-3.48^{\star}$ & $-2.93^{*}$ & $-2.59^{*}$ & $-2.16^{\star \star}$ & -1.90 \\
\hline \multirow{3}{*}{ HINDPET } & $V R$ & 0.036 & 0.018 & 0.012 & 0.009 & 0.006 & 0.005 & 0.003 & 0.002 \\
\hline & $Z(q)$ & $-7.81^{*}$ & $-5.55^{\star}$ & $-4.54^{*}$ & $-3.94^{*}$ & $-3.22^{\star}$ & $-2.79^{*}$ & $-2.28^{\star *}$ & $-1.97^{\star \star}$ \\
\hline & $Z^{\star}(q)$ & $-6.21^{\star}$ & $-4.66^{\star}$ & $-3.91^{\star}$ & $-3.45^{\star}$ & $-2.89^{\star}$ & $-2.54^{\star \star}$ & $-2.11^{\star \star}$ & -1.85 \\
\hline \multirow{3}{*}{ MRPL } & $V R$ & 0.036 & 0.018 & 0.013 & 0.009 & 0.006 & 0.005 & 0.003 & 0.002 \\
\hline & $Z(q)$ & $-7.81^{*}$ & $-5.55^{\star}$ & $-4.54^{*}$ & $-3.94^{*}$ & $-3.22^{\star}$ & $-2.79^{*}$ & $-2.28^{\star \star}$ & $-1.97^{\star \star}$ \\
\hline & $Z^{\star}(q)$ & $-5.53^{*}$ & $-4.23^{\star}$ & $-3.59^{*}$ & $-3.19^{*}$ & $-2.70^{*}$ & $-2.40^{\star *}$ & $-2.03^{\star *}$ & -1.80 \\
\hline \multirow{3}{*}{ ONGC } & $V R$ & 0.036 & 0.018 & 0.013 & 0.009 & 0.006 & 0.005 & 0.003 & 0.002 \\
\hline & $Z(q)$ & $-7.81^{\star}$ & $-5.55^{\star}$ & $-4.54^{*}$ & $-3.94^{*}$ & $-3.22^{\star}$ & $-2.79^{\star}$ & $-2.28^{\star *}$ & $-1.97^{\star \star}$ \\
\hline & $Z^{\star}(q)$ & $-5.99^{\star}$ & $-4.48^{\star}$ & $-3.76^{*}$ & $-3.32^{\star}$ & $-2.77^{\star}$ & $-2.43^{\star \star}$ & $-2.04^{\star \star}$ & -1.80 \\
\hline \multirow{3}{*}{ RELIND } & $V R$ & 0.035 & 0.018 & 0.012 & 0.009 & 0.006 & 0.005 & 0.003 & 0.002 \\
\hline & $Z(q)$ & $-7.82^{\star}$ & $-5.55^{\star}$ & $-4.54^{*}$ & $-3.94^{\star}$ & $-3.22^{\star}$ & $-2.79^{\star}$ & $-2.28^{\star \star}$ & $-1.97^{\star \star}$ \\
\hline & $Z^{*}(q)$ & $-5.35^{\star}$ & $-4.17^{\star}$ & $-3.57^{\star}$ & $-3.17^{\star}$ & $-2.66^{\star}$ & $-2.35^{\star \star}$ & $-1.98^{\star \star}$ & -1.76 \\
\hline \multirow{3}{*}{ RELINF } & $V R$ & 0.034 & 0.017 & 0.012 & 0.009 & 0.006 & 0.005 & 0.003 & 0.002 \\
\hline & $Z(q)$ & $-7.82^{\star}$ & $-5.56^{\star}$ & $-4.54^{*}$ & $-3.94^{\star}$ & $-3.22^{\star}$ & $-2.79^{\star}$ & $-2.28^{\star \star}$ & $-1.97^{\star \star}$ \\
\hline & $Z^{\star}(q)$ & $-4.99^{*}$ & $-3.86^{*}$ & $-3.29^{\star}$ & $-2.92^{\star}$ & $-2.45^{\star \star}$ & $-2.16^{\star \star}$ & -1.82 & -1.62 \\
\hline \multirow{3}{*}{ TATPWR } & $V R$ & 0.037 & 0.018 & 0.012 & 0.009 & 0.006 & 0.004 & 0.003 & 0.002 \\
\hline & $Z(q)$ & $-7.80^{*}$ & $-5.55^{\star}$ & $-4.54^{*}$ & $-3.94^{*}$ & $-3.22^{\star}$ & $-2.79^{\star}$ & $-2.28^{\star *}$ & $-1.97^{\star \star}$ \\
\hline & $Z^{\star}(q)$ & $-5.28^{*}$ & $-4.14^{\star}$ & $-3.53^{*}$ & $-3.12^{\star}$ & $-2.61^{\star}$ & $-2.30^{\star \star}$ & -1.93 & -1.72 \\
\hline \multirow{3}{*}{$\begin{array}{l}\text { ALL } \\
\text { Companies } \\
\text { (Average) }\end{array}$} & $V R$ & 0.039 & 0.020 & 0.014 & 0.010 & 0.007 & 0.005 & 0.003 & 0.002 \\
\hline & $Z(q)$ & $-7.78^{*}$ & $-5.54^{*}$ & $-4.54^{*}$ & $-3.93^{*}$ & $-3.22^{*}$ & $-2.79^{\star}$ & $-2.28^{\star *}$ & $-1.97^{\star \star}$ \\
\hline & $Z^{\star}(q)$ & $-5.17^{\star}$ & $-4.02^{\star}$ & $-3.45^{\star}$ & $-3.09^{\star}$ & $-2.62^{*}$ & $-2.31^{\star \star}$ & -1.95 & -1.73 \\
\hline
\end{tabular}

SOURCE: COMPUTED RESULTS BASED ON COMPILED DATA COLLECTED FROM CMIE PROWESS PACKAGE.

VR :Variance Ratio

$Z(q)$ : Estimated under the assumption of homoscedasticity

$Z^{*}(q)$ : Estimated under the assumption of heteroscedasticity

*Significant at the $1 \%$ level; **Significant at the $5 \%$ level. 
Furthermore, the test statistics estimated under the assumption of both homoscedasticity and heteroscedasticity are also significant for all 12 companies of the Energy and Utilities sector for all lags. Hence, $H_{0}^{2}$ "returns of the 12 companies of the Energy and Utilities sector in India follow a random walk" is rejected both for the short-run as well as for the long-run for all the companies of the sector, which indicates nonrandom behaviour in the return series of all the companies.

\section{Summary and conclusion}

The main objective of the study is to investigate the relationship between the conditional mean and the conditional variance using daily returns of individual companies from the Energy and Utilities sector of India's BSE 500 for the period from $1^{\text {st }}$ January 2003 to $31^{\text {st }}$ December 2012. The results of testing the relationship between stock returns and volatility of 12 individual stocks of the Energy and Utilities sector reveal that of these twelve stocks, only one shows a significant result. This indicates a direct relationship between risk and return in only one of the cases; for all the other companies, according to the GARCH-M $(1,1)$ model, the relationship is not significant. Furthermore, none of the companies' behaviour of returns follows a RW, hence the findings conclusively demonstrate that the returns of the selected companies from the Energy and Utilities sector exhibit non-random behaviour in both the long-run as well as in the short-run.

The study used the GARCH-M $(1,1)$ model since most researchers tend to consider it an excellent model for estimating the conditional volatility of a wide range of financial data. Compared to the CAPM model, the GARCH-M model allows the conditional variance $\left(\sigma^{2}\right)$ of return as a measure of risk, thereby predicting the relationship between risk and return.

The study supports the findings of previous studies of Karmakar (2005) and Zivanayi and Chinzara (2012). The results, however, contradict those of Karmakar (2007), which found the risk premium to be significant, whereas the present study found a significant result for only one company, with all the other companies showing an insignificant relationship between risk and return.

The present study examined the risk-return dynamics of stocks of the Energy and Utilities sector of the BSE 500. This study could be extended to address other sectors of the BSE and could also make cross-sector comparisons. There is also a need to broaden the study by concentrating on the other macro and market factors which affect the Indian SM, in addition to the relationship between risk and return, especially the relationship between risk and return. 


\section{Suggestions for policy prescriptions}

Firstly, given that stock returns play a vital role in the Indian economy, the findings of this study have a number of important implications for future practices and contribute to the clear need to determine the relationship between risk and returns of stocks. Secondly, in light of the insignificant relationship demonstrated between risks and returns of all companies except CPCL, investors should be advised to invest in stock carefully. Finally, the findings of the present study are relevant since they help investors to better understand an emerging economy such as India.

\section{References}

Ajayi, R.A. and Karemera, D. (1996). A variance ratio test of random walks in exchange rates: Evidence from Pacific Basin economies, Pacific-Basin Finance Journal, 4(1), pp. 77-91.

Baillie, R.T., and DeGennaro, R P. (1990).Stock return and volatility, Journal of Financial and Quantitative Analysis, 25(2), pp. 203-214.

Bollerslev, T. (1986). Generalized autoregressive conditional heteroskedasticity, Journal of Econometrics, 31(3), pp. 307-327.

Bark, H.K.H. (1991). Risk, return, and equilibrium in the emerging markets: Evidence from the Korean stock market, Journal of Economics and Business, 43(4), pp. 353-362.

Black, F. (1990). Mean reversion and consumption smoothing, Review of Financial Studies, 3(1), pp. 107-114.

Budd, B.Q. and McCrohan, D. (2012). Sensitivity of sector risk-return relationship in the Saudi Arabian stock market, International Research Journal of Finance and Economics, 85, pp. 101-110.

Cecchetti, S.G., Pok-Sam, L. and Mark, N.C. (1990). Mean reversion in equilibrium asset prices, American Economic Review, 80(3), pp. 398-418.

Chand, S., Kamal, S. and Ali, I. (2012). Modelling and volatility analysis of share prices using ARCH and GARCH models, World Applied Sciences Journal, 19(1), pp. 77-82.

Chen, J.H. (2008). Variance ratio tests of the random walk hypothesis of the Euro exchange rate, International Business \& Economics Research Journal, 7(12), pp. 97-106.

Choudhary, K. and Choudhary, S. (2010). Testing capital asset pricing model: Empirical evidences from Indian equity market, Eurasian Journal of Business and Economics, 3(6), pp. 127-138.

Dean, W.G. and Faff, R.W. (2001). The inter-temporal relationship between market return and variance: An Australia perspective, Accounting and Finance, 41, pp. 169-196.

Dickey, D.A. and Fuller, W.A. (1979). Distribution of the estimators for autoregressive time series with a unit root, Journal of American Statistical Association, 74(366), pp. 427-431. 
Engle, R.F. (1982). Autoregressive conditional heteroscedasticity with estimates of the variance of United Kingdom inflation, Econometrica, 50(4), pp. 987-1007.

Engle, R.F., Lilien, D. and Robins, R.P. (1987). Estimating time varying risk premia in the term structure: The ARCHM model, Econometrica, 55(2), pp. 391-407.

French, K.R., Schwert, G.S. and Stambaugh, R.F. (1987). Expected stock returns and volatility, Journal of Financial Economics, 19(1), pp. 3-29.

Gul, A. and Khan, N. (2013). An application of arbitrage pricing theory on KSE-100 Index; A study from Pakistan (2000-2005), IOSR Journal of Business and Management, 7(6), pp. 78-84.

Iqbal, J. and Brooks, R. (2007). A test of CAPM on the Karachi stock exchange, International Journal of Business, 12(4), pp. 429-444.

- Jog, V. and Schaller, H. (1994). Finance constraints and asset pricing: Evidence on mean reversion, Journal of Empirical Finance, 1(2), pp. 193-209.

Karmakar, M. (2005). Modelling conditional volatility of the Indian stock markets, Vikalpa, 30(3), pp. 21-37.

Karmakar, M. (2007). Asymmetric volatility and risk-return relationship in the Indian stock market, South Asia Economic Journal, 8(1), pp.99-116.

Kim, M.J., Nelson, R.C. and Startz, R. (1991). Mean reversion in stock prices? A reappraisal of the empirical evidence, The Review of Economic Studies, 58(3), pp. 515-528.

Lo, A.W. and MacKinlay, A.C. (1988). Stock market prices do not follow random walks: Evidence from a simple specification test, Review of Financial Studies, 1(1), pp. 41-66.

Malik, F. and Hassan, S.A. (2004). Modelling volatility in sector index returns with GARCH model using an integrated algorithm, Journal of Economics and Finance, 28(2), pp. 211-225.

Michailidis, G. and Tsopoglon, S. (2007). Beta and returns revisited: Evidence from international stock markets, Management of International Business \& Economic Systems, 1(1), pp. 74-85.

Mbululu, D., Auret, C.J. and Chiliba, L. (2013). Do exchange rates follow random walk? A variance ratio test of the Zambian foreign-exchange market, Southern African Business Review, 17(2), pp. 45-66.

Nateson, C., Palanisamy, R. Renukadevi, P. and Suganya, D. (2013). Spill over effect of volatility in BSE Sensex on BSE sector-wise indices, International Journal of Management and Business Studies, 3(1), pp. 92-95.

Poterba, J. and Summers, L. (1988). Mean reversion in stock returns: Evidence and implications, Journal of Financial Economics, 22(1), pp. 27-59.

Sentana, E. (1997). Risk and return in the Spanish stock market: Some evidence from individual assets, Investigaciones Económicas, 21(2), pp. 297-359.

Shanmugasundram, G. and Benedict, J. (2013). Volatility of the Indian indices of sectors - A study with reference to national stock exchange, International Journal of Marketing, Financial Services and Management Research, 2(8), pp. 1-11.

Tah, K.T. (2013). Relationship between volatility and expected returns in two emerging markets, Business and Economics Journal, 84, pp. 1-7. 
Tang, G.Y.N. and Shum, W.C. (2003). The conditional relationship between beta and returns: Recent evidence from international stock market, International Business Review, 12(1), pp. 109-126.

Wen, C.C. (2009). A variance ratio test of random walk in energy spot markets, Journal of Quantitative Economics, 8(1), pp. 105-117.

White, H. (1980). A heteroskedasticity-consistent co-variance matrix and a direct test for heteroskedasticity, Econometrica, 48(4), pp. 817-838.

Zivanayi, N.M. and Chinzara, Z. (2012). Risk-return trade-off and behaviour of volatility on the South African stock market: Evidence from both aggregate and disaggregate data, South African Journal of Economics, 80(3), pp. 345-366.

\section{Appendix}

\section{List of companies selected for the study with abbreviations}

\begin{tabular}{clc}
\hline S. No. & \multicolumn{1}{c}{ Firm } & Abbreviations \\
\hline 1. & Bharat Petroleum Corpn. Ltd. & BHARPET \\
\hline 2. & Chennai Petroleum Corpn. Ltd. & CPCL \\
\hline 3. & GAIL (India) Ltd. & GAIL \\
\hline 4. & Gujarat Gas Co. Ltd. & GUJGAS \\
\hline 5. & Hindustan Oil Exploration Co. Ltd. & HINDOIL \\
\hline 6. & Hindustan Petroleum Corpn. Ltd. & HINDPET \\
\hline 7. & Mangalore Refinery \& Petrochemicals Ltd. & MRPL \\
\hline 8. & Oil \& Natural Gas Corpn. Ltd. & ONGC \\
\hline 9. & Reliance Industries Ltd. & RELIND \\
\hline 10. & CESC Ltd. & CESC \\
\hline 11. & Reliance Infrastructure Ltd. & RELINF \\
\hline 12. & Tata Power Co. Ltd. & TATPWR \\
\hline
\end{tabular}

SOURCE: CMIE PROWESS PACKAGE. 